\title{
Is There a Non-Zero Stable Component in the Eurozone's External Balances?
}

\author{
Carlos A. Carrasco*
}

Departamento de Economía, Universidad de Monterrey (UDEM), N.L., Mexico

\begin{abstract}
We consider the potential presence of a structural component in the external balance of 12 Eurozone countries. To this aim, we define the Structural Component of the External Balance as the unobservable part of the external balance that is stable or evolves slowly and around which fluctuations occur with a potentially cyclical origin that are corrected in the shortterm. We propose a methodology for obtaining the Structural Component of the External Balance by decomposing the external balance using breakpoint tests, and we contrast this methodology against other methods widely used in the economic literature. Moreover, we investigate the factors that determine the Structural Component of the External Balance of Eurozone countries. According to our results, Belgium, Germany, Luxembourg, and the Netherlands have a structural and persistent surplus, whereas Greece, Portugal, and Spain have structural deficits. Furthermore, our results indicate that export specialization, financial openness, and a government deficit/surplus are the key variables explaining the Structural Component of the External Balance.
\end{abstract}

JEL Classifications: F15, F32, F36

Keywords: European external imbalances, Structural external balance, Economic specialization, Financial liberalization, Economic integration

\footnotetext{
* Corresponding Author: Carlos A. Carrasco; Professor, Departamento de Economía, Universidad de Monterrey (UDEM). Av. Ignacio Morones Prieto 4500 Pte., C.P. 66238, San Pedro Garza García, Nuevo León, México; Telephone: (0052) 81 8215-1000 ext. 3892; Email: carlos.carrasco@udem.edu.
} 


\section{Introduction}

The recent economic literature has extensively analyzed the origin of external imbalances among Eurozone member states. Thus, some factors underlying these external imbalances have been identified, such as (1) the expected catching-up process between Eurozone member states, as identified by Gehringer (2015), Belke and Dreger (2013), Schmitz and von Hagen (2011), Campa and Gavilan (2011), and Blanchard and Giavazzi (2002); (2) differences in price and non-price competitiveness as discussed by Belke and Dreger (2013), Chen, Milesi-Ferretti, and Tressel (2013), Arghyrou and Chortareas (2008), and Blanchard (2007); (3) the role of the public sector, as examined by Alessandrini et al. (2014), Algieri (2013), Brissimis et al. (2013), Barnes, Lawson, and Radziwill (2010), and Blanchard (2007); (4) differences in demographic structures, as identified by Aizenman and Sengupta (2011), Hassan, Salim, and Bloch (2011), and Barnes, Lawson, and Radziwill (2010); and (5) the development of the financial systems, as found by Gehringer (2015), Schmitz and von Hagen (2011), and Lane (2010).

However, in the Eurozone case, the existing literature has overlooked the possible presence of a Structural Component of the External Balance (SCEB). Some indicators point to the potential presence of a SCEB, such as the persistence of external imbalances regardless of which part of the economic cycle countries are in, the existence of these imbalances before and after the adoption of the euro, and the relationship between these imbalances and the economic structure, for instance, economic specialization.

To clarify this issue, we identify and measure the existence and the determinants of the structural component of Eurozone countries' external imbalances. We focus on the group of initial countries to join the Eurozone (Austria, Belgium, Finland, France, Germany, Ireland, Italy, Luxembourg, Netherlands, Portugal, and Spain) plus Greece, which are commonly known as the Euro Area-12 (hereafter EA-12). Our analysis is restricted to the EA-12 group due to data unavailability for other Eurozone configurations. Existence of SCEB in a country's external imbalances implies that such a SCEB would be structurally skewed toward persistent deficits or surplus. Solving it would require changing the structure of the relations between the country and its partners. The first step would be to identify the SCEB and its determinants.

This paper has twofold aims. On the one hand, we aim to identify evidence 
for a structural component in Eurozone external imbalances. We define and propose a methodology for identifying the SCEB, which we call Structural Component by Breakpoints (hereafter SCBp). In this approach, the SCEB is defined as the unobservable part of the external balance that is stable or evolves slowly regardless of which part of the economic cycle the economy is in and around which fluctuations exist with a potentially cyclical origin that are corrected in the short term. Once we have identified the structural component, we implement cross-section and panel data techniques to investigate the determinants of this structural component. We compare our methodological proposal, i.e., SCBp, with other techniques commonly used in the economic literature.

The article is structured as follows. The second section presents some stylized facts about Eurozone external imbalances. The third section develops a theoretical approach to the presence of that component and proposes a definition of and method for identifying the SCEB. The fourth section analyzes the determinants of the SCEB for EA-12 countries. Lastly, we make final remarks and discuss the economic policy implications of our results.

\section{Stylized Facts and European External Imbalances}

The presence of external imbalances has been observed among Eurozone members, the dimensions of which have risen since the adoption of the single currency. Figure 1 shows a stacked plot of the balances for current transactions with the rest of the world, retrieved from the Annual MacroEconomic database (AMECO) for the EA-12 countries. This series is used in this paper's analyses because of its longer time coverage (available from 1960) than the current account balance series. In addition, use of this series avoids problems related to a change in the methodology (compilation of a country's balance of payments) when the Balance of Payments and International Investment Position Manual (BPM6) of the International Monetary Fund was implemented. The balance of current transactions with the rest of the world (hereafter BRM) is the sum of net exports of goods and services, net primary income, and net current transfers, the latter two from the rest of the world. ${ }^{1}$

${ }^{1}$ According to the AMECO annotation, "[t]he Current external balance is the balancing item in the external account of primary incomes 
Figure 1. Balance on current transactions with the rest of the world

Mrd ECU/euros)

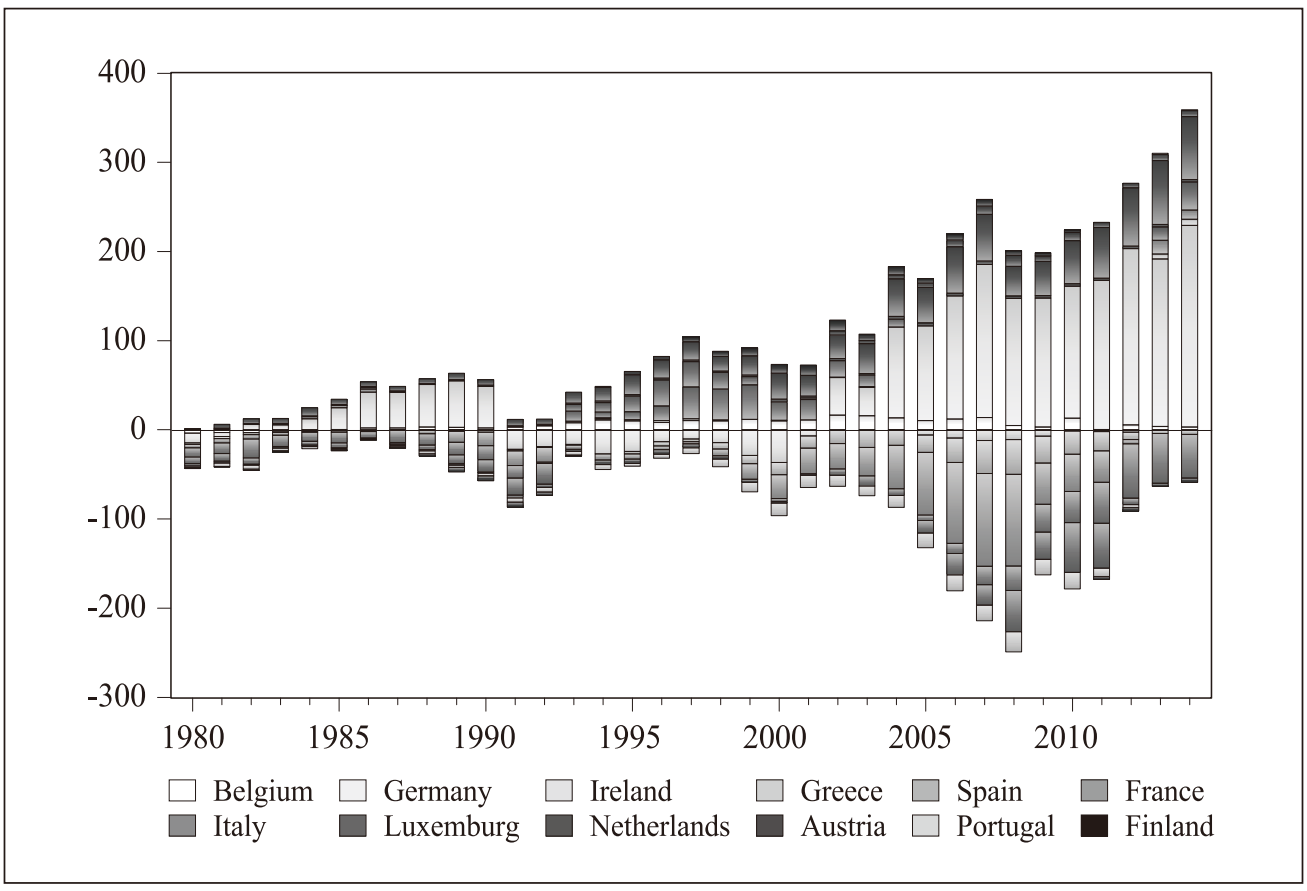

(Source) AMECO

Figure 1 reveals the presence of significant and persistent imbalances among EA-12 member states, starting in the initial years of the euro's adoption, especially since 2003 2004. In this regard, Lane (2010) points out that European imbalances should be seen as part of an international balance sheet in which the years 2003 and 2004 marked the beginning of a worldwide credit boom. This boom was accompanied by a reconfiguration of the international monetary system through innovations in financial instruments and securitization, which resulted in diversification and a decrease (in technical terms) of financial risk. Thus, in absolute terms, Germany has the highest surplus within the EA-12 group. Other countries that showed, and still show, persistent surpluses are the Netherlands, Finland, Luxembourg, and Austria. In contrast, Spain, Greece, Portugal, and Ireland showed significant

and current transfers. It represents the surplus or the deficit of the total economy on its current transactions with the rest of the world. The current transactions comprise trade in goods and services, primary incomes and current transfers.". 
and persistent deficits. However, at the aggregate level, that is, considering the EA-12 as a whole, the external balance is close to equilibrium. Finally, Figure 1 shows a correction of external imbalances in deficit countries associated with the fall in income due to the international financial crisis and the European sovereign debt crisis.

Figure 2. Balance on current transactions with the rest of the world (\% GDP) and Gap between actual and potential gross domestic product

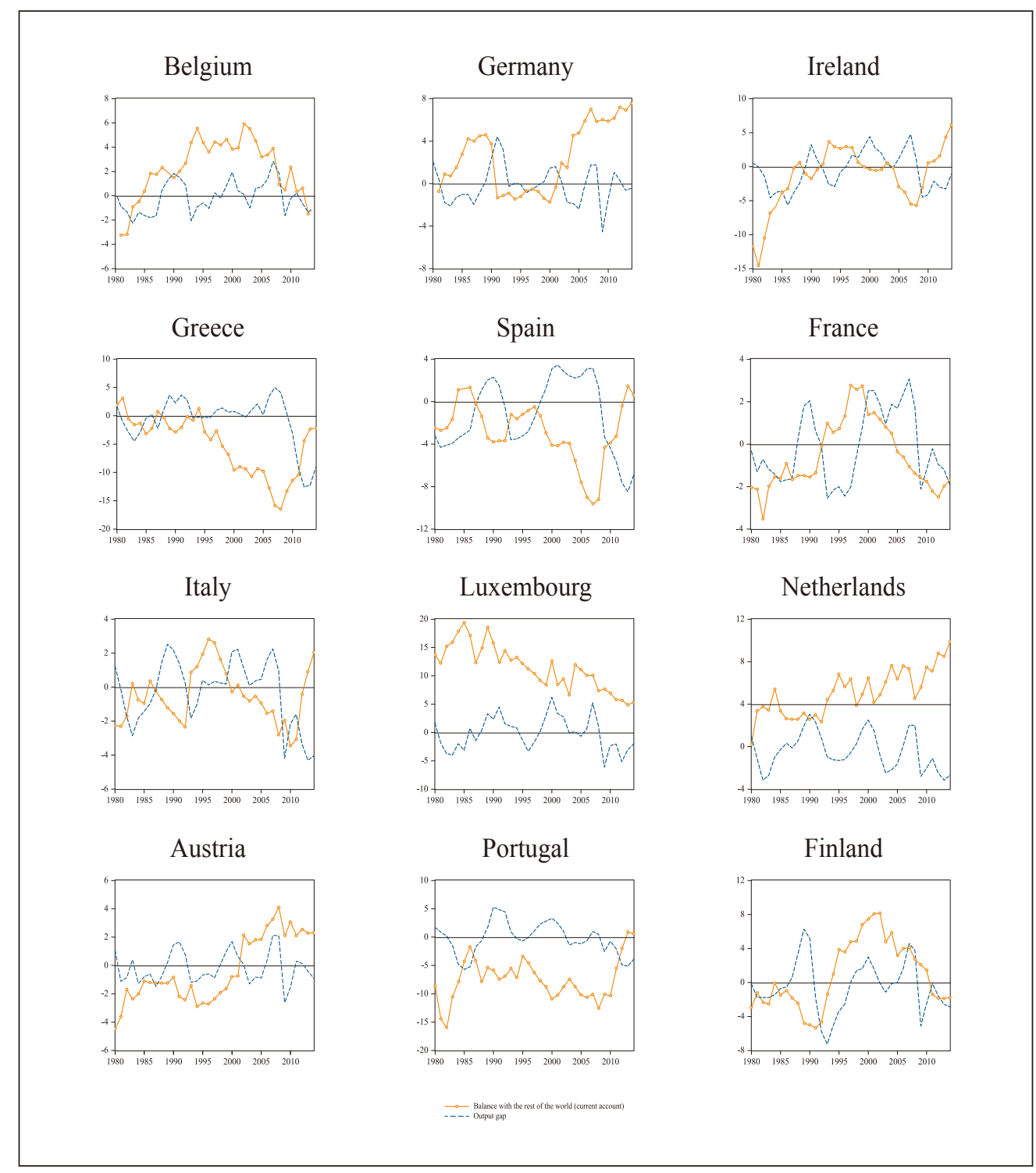


As noted in the introductory section, the economic literature has identified different factors behind these imbalances. However, studies have not considered either the presence of a SCEB or its determinants for the Eurozone case in-depth. In this regard, several clues point to the presence of a SCEB. Figure 2 shows a series of BRM and the output gap for EA-12 countries in the 1980 2014 period. $^{2}$ Our analysis focuses on countries that have presented significant and persistent surpluses or deficits. On the one hand, Greece, Spain, and Portugal -characterized by persistent deficits before the criseshave substantially corrected their external deficits since the outbreak of the global financial crisis. However, these corrections are associated with a fall in income, that is, with a negative output gap. This association suggests that once economies return to their level of potential growth, external deficits will potentially reappear. Thus, recovery signs were accompanied by the reappearance of external deficits, as seen in recent years. All in all, the presence of structural and persistent external balances is expected when those economies recover their potential growth level. On the other hand, in the cases of Germany, Luxembourg, Netherlands, and Austria, a negative output gap-associated with the global financial crisis and the European sovereign debt crisis-did not significantly alter the persistence of the external surpluses that have characterized those economies at least since the adoption of the euro.

Finally, Figure 3 contrasts -through a scatter plot using data for EA-12 countries in the period 1999 to 2014 to contrast- the BRM variable against some variables tentatively related to the SCEB. On the one hand, Figure 3 shows that external balances are positively related to the research and development expenditure (R\&D) and high-tech exports (representing the economic structure and country specialization) as well as regulatory quality (institutional factors) and GDP per capita (development stage). On the other hand, a negative relationship exists between the old-age dependency ratio (demographic structure) and the external balance. These traitsclues lead us to investigate the potential presence of a SCEB.

${ }^{2}$ The output gap is measure by AMECO as the gap between actual GDP and potential GDP as a percentage of potential GDP. 
Figure 3. Balance on current transactions with the rest of the world (\% GDP) versus relevant structural variables
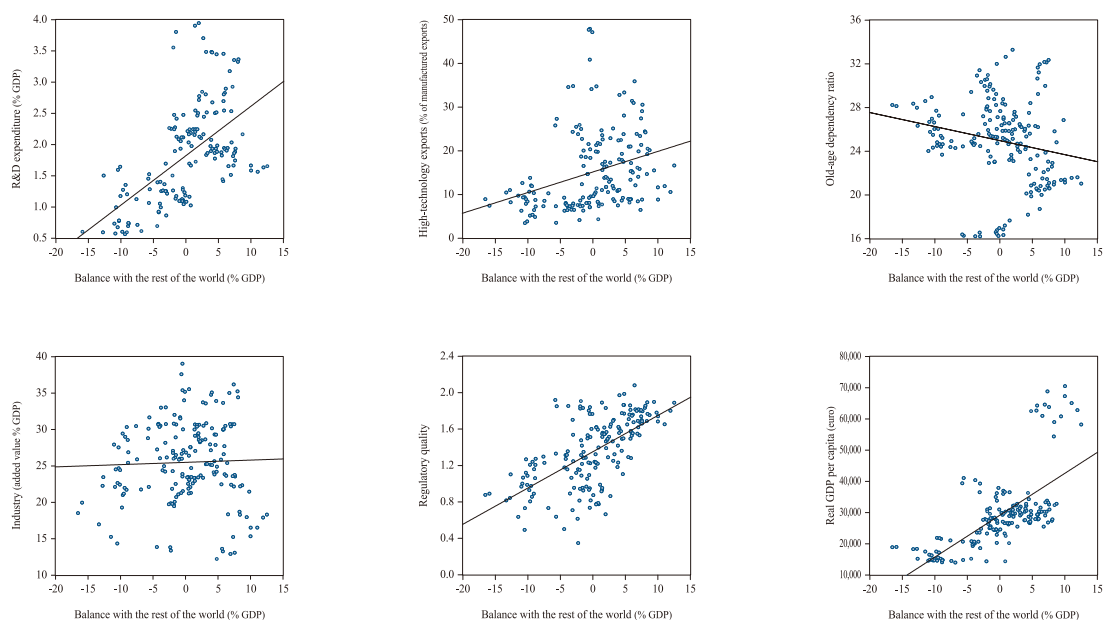

\section{Proposal for Identifying the SCEB}

Theoretically, the presence of the SCEB can be modeled from Equation 1 based on the decomposition of balance with the rest of the world, $B R M_{i, t}$, on a cyclically adjusted component, $B R M_{i, t}^{Y^{p}}$, and a component that depends on the output gap, $\beta\left(Y_{i, t}^{p}-Y_{i, t}\right)$ :

$$
B R M_{i, t}=B R M_{i, t}^{Y^{p}}+\beta\left(Y_{i, t}^{p}-Y_{i, t}\right)
$$

where $B R M_{i, t}^{Y^{p}}$ is an unobservable variable defined as the balance with the rest of the world when the economy is at its potential level -that is, when $Y_{i, t}^{p}=Y_{i, t}$ - and $\beta\left(Y_{i, t}^{p}-Y_{i, t}\right)$ is the cyclical component of the external balance that is different from zero when the economy deviates from its potential growth level $\left(Y_{i, t}^{p} \neq Y_{i, t}\right)$, where $\beta$ is a parameter measuring the effect of deviations of actual output from its potential level on the external balance. In this case, $B R M_{i, t}^{Y^{p}}$ is interpreted as the structural component of the BRM series.

Equation (1) is a first approach to theoretical analysis of the SCEB. 
Assuming $Y_{i, t}^{p}=Y_{i, t}$, then the external balance would be determined by the cyclically adjusted component. This allows us to analyze whether a deficit or surplus is present in an economy's external balance when that economy $\mathrm{i}$ is operating at its potential level. In addition, after identifying the cyclically adjusted component, the next step is to analyze the determinants of the SCEB. In this regard, Equation 2 is an approximation of the determinants of the structural component of the external balance:

$$
B R M_{i, t}^{Y^{p}}=\alpha_{1}+\alpha_{2} S_{i, t}+\alpha_{3} D_{i, t}+\alpha_{4} I_{i, t}+\alpha_{5} F_{i, t}+\alpha_{6} G_{i, t}
$$

Here $B R M_{i, t}^{Y^{p}}$ is the SCEB, $S_{i, t}$ is a set of variables related to the economic structure (specialization), $D_{i, t}$ is a set of demographic variables, $I_{i, t}$ is a set of institutional factors, $F_{i, t}$ is a set of variables related to the financial structure, and $G_{i, t}$ is a set of variables representing the role of the public sector. ${ }^{3}$

The first problem that arises when analyzing the SCEB is that no consensus exists regarding its definition. However, some characteristics have been identified that could help to define the structural component. First, it is important to differentiate between the structural component and cyclical component of the external balance. Unlike in the cyclic part, a change in the structural component is slow or originates from structural breaks (e.g., German reunification or introduction of the euro). Therefore, the SCEB is the element of the external balance that remains stable over time or evolves slowly. Secondly, fluctuations exist around the structural component, which has a potentially cyclical origin or results from transitory shocks. Third, given the potentially cyclical origin or transitory nature of those fluctuations, deviations from the structural component are corrected in the short term. Finally, SCEB is an unobservable variable, and therefore its analysis requires decomposition of the external balance by means of statistical methods and/or econometric techniques. Based on these characteristics, we define the SCEB as follows:

${ }^{3}$ In section 4, we return to Equation (2) to analyze the determinants of the structural component of the EA-12 countries' external balance of the EA-12 countries. 
Definition 1: The SCEB is the unobservable part of the external balance that is either stable or evolves slowly regardless of which part of the economic cycle the economy is in and around which fluctuations exist with a potentially cyclical origin that are corrected in the short term.

The economic literature related to the identification and estimation of unobservable components -in the case of the SCEB- can be divided into statistical techniques that decompose the series (e.g., a trend and a cycle) or econometric techniques that include the economic properties of the series (e.g., by using a production function). For instance, in the case of structural unemployment, the EU Directorate General for Economic and Financial Affairs (ECFIN) uses a Kalman filter to decompose the trend and cycle in the series of unemployment, as in Orlandi (2012). ${ }^{4}$ On the other hand, the Economic and Financial Affairs Council (ECOFIN) obtains potential output using a production function based on the economy's theoretical potential supply, as stated by D'Auria et al. (2010). Both techniques have advantages and disadvantages. In the first case, the purely statistical techniques could be unrelated to the specific context of the series; therefore, these techniques treat different economic variables as equal. In the second case, restrictive assumptions are made about the functional form of the production function.

In the economic literature, different techniques have been used when analyzing the structural external balance (in some cases, it is proxied by the medium-term trend). In the seminal article of Chinn and Prasad (2003), medium-term trends are proxied through non-overlapping 5-year averages while medium-term determinants are analyzed by implementing ordinary least squares on a panel framework with time effects. This methodology has been used to analyze the structural factors behind the current account for a series of 94 countries by Cheung, Furceri, and Rusticelli (2013). However, a disadvantage of this methodology relates to the discretionary selection of the 5-year period, which could bias the results. Meanwhile, the Deutsche Bundesbank (2001) uses the Hodrick-Prescott filter as proposed by Hodrick and Prescott 1997) to analyze the structural current account with a simple absorption approach. However, filtering techniques can bias the structural component (trend) by positively correlating the trend component 
with the cyclical component. This trend component is skewed even when a strong deviation is temporal. Finally, Matsubayashi (2006) considers the intertemporal decisions of households and firms and defines the structural current account as the part of the current account that is explained by the optimal behavior of individuals under full employment. However, this methodology is not free from criticism: it makes strong assumptions about the functional form of the relationships between variables and when the author obtains the dependent variables.

We propose a method for identifying the SCEB for the EA-12 countries, which we call SCBp. In line with our aforementioned definition of the SCEB, variations exist around the structural component; these are characterized as temporary deviations that are corrected in the short term.

Our proposal consists of four steps and three criteria:

Step 1: Implement Bai-Perron breakpoint tests as proposed by Bai (1997) and Bai and Perron $(1998,2003)$ to identify breaks in the series. The auxiliary regression only includes a constant as regressor reflecting the structural component, which, according to our definition, is stable or evolves slowly.

Step 2: In accordance with breakpoint dates, obtain the average of the series for each sub-period $j$ for the country $i, \overline{B R M}_{i, j}$. In our SCBp proposal, $\overline{B R M}_{i, j}$ is the SCEB.

Step 3: To test the validity of our definition regarding the temporal dimension of deviations from the structural component, construct an auxiliary variable using the difference between the actual variable in $t$ and the corresponding sub-period $j$ average for the country $i$, that is, $\overline{B R M}_{i, j}$. Let $y_{i, t}$ be our auxiliary variable for country $i$ in time $t$, and BRM our relevant variable. Then, we have

$$
y_{i, t}=B R M_{i, t}-\overline{B R M}_{i, j}
$$

where $B R M_{i, t}$ is the relevant actual variable in time $t$ for country $i$, and $\overline{B R M}_{i, j}$ is the average of the relevant variable for country $i$ in the 
corresponding sub-period $j$.

Step 4: After obtaining the auxiliary variable, implement DickeyFuller unit root tests as in Dickey and Fuller (1979, 1981; hereafter ADF) and Phillips-Perron unit root tests as in Phillips and Perron (1988; hereafter PP) to determine the order of integration for the auxiliary variable. Centring the variable with respect to the corresponding sub-period average prevents structural changes from biasing the results of the unit root tests toward the non-rejection of the null hypothesis (Type II error). Our proposal is only suitable when unit root tests reject the null hypothesis.

Having implemented these four steps outlined, we propose three criteria for identifying the existence of a structural deficit/surplus in the relevant variable:

Criterion 1: Sub-period averages should be different from zero.

Criterion 2: Unit root tests should show that the auxiliary variable for country $i$ is $\mathrm{I}(0)$, suggesting that any deviation from the average will be corrected in the short term. Furthermore, by centring the variable with respect to the corresponding sub-period average, the constant regressor in the unit root test auxiliary regressions is not expected to be significant.

Criterion 3: A higher number of breaks with changing signs indicates a higher possibility of cyclical movements, whereas fewer breaks and/or persistence in the signs between consecutive sub-periods indicates the existence of structural imbalances.

An advantage of our proposed approach is that the starting year of each period is not selected in a discretionary manner but by implementing breakpoint tests. Furthermore, use of unit root tests allows us to identify whether variations around the structural component are temporary and whether the implementation of the SCBp proposal is suitable. In addition, decomposing the external balance using the SCBp proposal means that the presence of a strong temporal deviation will not significantly skew the result 
of the SCEB, unlike when filtering techniques are implemented. Finally, our SCBp proposal does not require strong assumptions regarding the variables' functional form. However, the SCBp proposal has two main disadvantages. On the one hand, when the goal is to analyze the determinants of the structural component, this technique can lead to having too few observations. This can be remedied by increasing the number of countries in the sample, but only provided that countries included in the sample are relatively homogeneous. On the other hand, if the goal is the early detection of imbalance's structural component, the approach is of limited benefit because, according to our proposal, the structural component cannot be identified in real time.

For the empirical analysis, as noted above, the BRM series is used as a proxy for the external balance due to its availability for all members of the EA-12 for a longer span of time (1960 2014). Table 1 shows the results of Bai-Perron breakpoint tests for each of the members of the EA-12 and the corresponding BRM variable's sub-period averages of the BRM variable. The country showing the highest number of breaks is Belgium (four breaks), while countries with fewer numbers of breaks were experienced by Greece, Italy, Portugal, and Spain (only one break each). As seen in the second part of Table 1, the sub-period averages according to the Bai-Perron breakpoint tests are different from zero for Austria (since the sub-period beginning in 1976), for Belgium (in all sub-periods), for Finland (before the period that coincides with the global financial crisis), for France (since the sub-period beginning in 1974), for Greece (since the adoption of the single currency) , for Ireland (up until 1987), for Luxembourg, for the Netherlands (since 1969, with a significant increase in 1993 and then in 2004), for Portugal (for the entire period with a sharp deterioration since 1974), and for Spain (with further deterioration since the adoption of the single currency). In the case of Germany, since the sub-period beginning in 1983, the country appears to have had a structural surplus with the exception of the third sub-period (1991 2003), which is related to German reunification, as is highlighted by thein Deutsche Bundesbank (2001).

Finally, unit root tests reported in Table 2 indicate that auxiliary variable $y_{i, t}$ is integrated of order 0 for each of the EA-12 member countries, which means that any deviation from the sub-period average (proxy for the SCEB) will be corrected in the short term. As expected, the constant regressor in the auxiliary unit root test regressions is not statistically significant. 
Overall, it is possible to identify the presence and persistence of a structural surplus in Belgium (moderate surplus), Germany, Luxembourg, and the Netherlands, whereas Greece (mainly since the adoption of the euro), Portugal, and Spain have experienced structural deficits. 


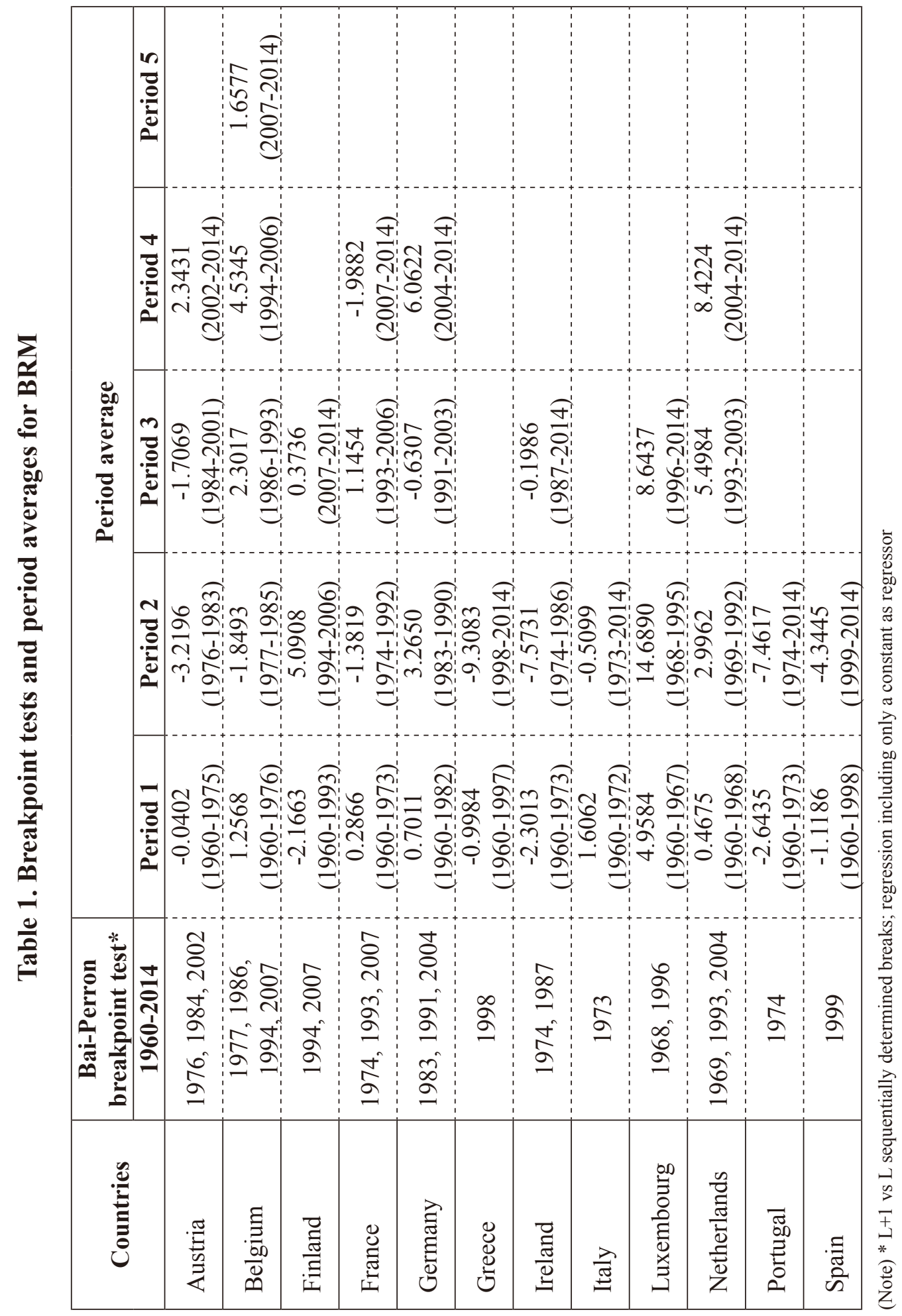


Table 2. Unit Root tests for auxiliary variable

\begin{tabular}{|c|c|c|c|c|c|}
\hline \multirow[t]{2}{*}{ Countries } & \multicolumn{2}{|c|}{$\begin{array}{c}\text { Augmented } \\
\text { Dickey-Fuller }\end{array}$} & \multicolumn{2}{|c|}{ Phillips-Perron } & \multirow{2}{*}{$\begin{array}{l}\text { Integration } \\
\text { order }\end{array}$} \\
\hline & Levels & 1st difference & Levels & 1st difference & \\
\hline Austria & $\begin{array}{l}-5.7685 \\
(0.0000)\end{array}$ & $\begin{array}{l}-8.9670 \\
(0.0000)\end{array}$ & $\begin{array}{l}-5.7685 \\
(0.0000)\end{array}$ & $\begin{array}{r}-14.6385 \\
(0.0000)\end{array}$ & $\mathrm{I}(0)$ \\
\hline Belgium & $\begin{array}{l}-5.0667 \\
(0.0000)\end{array}$ & $\begin{array}{l}-9.2152 \\
(0.0000)\end{array}$ & $\begin{array}{l}-4.8979 \\
(0.0000)\end{array}$ & $\begin{array}{c}-18.5676 \\
(0.0000)\end{array}$ & $\mathrm{I}(0)$ \\
\hline Finland & $\begin{array}{l}-3.9596 \\
(0.0002)\end{array}$ & $\begin{array}{l}-8.3271 \\
(0.0000)\end{array}$ & $\begin{array}{l}-3.9827 \\
(0.0002)\end{array}$ & $\begin{array}{l}-11.9708 \\
(0.0000)\end{array}$ & $\mathrm{I}(0)$ \\
\hline France & $\begin{array}{l}-4.6330 \\
(0.0000)\end{array}$ & $\begin{array}{l}-8.6348 \\
(0.0000)\end{array}$ & $\begin{array}{l}-4.6052 \\
(0.0000)\end{array}$ & $\begin{array}{r}-11.7968 \\
(0.0000)\end{array}$ & $\mathrm{I}(0)$ \\
\hline Germany & $\begin{array}{l}-5.3071 \\
(0.0000)\end{array}$ & $\begin{array}{l}-8.2669 \\
(0.0000)\end{array}$ & $\begin{array}{l}-3.6082 \\
(0.0005)\end{array}$ & $\begin{array}{r}-10.7669 \\
(0.0000)\end{array}$ & $\mathrm{I}(0)$ \\
\hline Greece & $\begin{array}{l}-3.598 \\
(0.0006)\end{array}$ & $\begin{array}{l}-6.3618 \\
(0.0000)\end{array}$ & $\begin{array}{l}-2.8093 \\
(0.0058)\end{array}$ & $\begin{array}{l}-6.3512 \\
(0.0000)\end{array}$ & $\mathrm{I}(0)$ \\
\hline Ireland & $\begin{array}{l}-3.3260 \\
(0.0013)\end{array}$ & $\begin{array}{l}-7.6836 \\
(0.0000)\end{array}$ & $\begin{array}{l}-3.5021 \\
(0.0007)\end{array}$ & $\begin{array}{l}-7.6836 \\
(0.0000)\end{array}$ & $\mathrm{I}(0)$ \\
\hline Italy & $\begin{array}{l}-3.4762 \\
(0.0008)\end{array}$ & $\begin{array}{l}-7.7008 \\
(0.0000)\end{array}$ & $\begin{array}{l}-3.6074 \\
(0.0005)\end{array}$ & $\begin{array}{l}-8.2036 \\
(0.0000)\end{array}$ & $\mathrm{I}(0)$ \\
\hline Luxembourg & $\begin{array}{l}-5.8041 \\
(0.0000)\end{array}$ & $\begin{array}{l}-6.4366 \\
(0.0000)\end{array}$ & $\begin{array}{l}-5.7186 \\
(0.0000)\end{array}$ & $\begin{array}{l}-23.9571 \\
(0.0000)\end{array}$ & $\mathrm{I}(0)$ \\
\hline Netherlands & $\begin{array}{l}-5.0783 \\
(0.0000)\end{array}$ & $\begin{array}{l}-8.0442 \\
(0.0000)\end{array}$ & $\begin{array}{l}-4.1756 \\
(0.0001)\end{array}$ & $\begin{array}{l}-8.1956 \\
(0.0000)\end{array}$ & $\mathrm{I}(0)$ \\
\hline Portugal & $\begin{array}{l}-3.5654 \\
(0.0006)\end{array}$ & $\begin{array}{l}-7.9195 \\
(0.0000)\end{array}$ & $\begin{array}{l}-3.1381 \\
(0.0023)\end{array}$ & $\begin{array}{l}-8.2891 \\
(0.0000)\end{array}$ & $\mathrm{I}(0)$ \\
\hline Spain & $\begin{array}{l}-3.6695 \\
(0.0004)\end{array}$ & $\begin{array}{l}-5.6794 \\
(0.0000)\end{array}$ & $\begin{array}{l}-2.9683 \\
(0.0037)\end{array}$ & $\begin{array}{l}-5.6388 \\
(0.0000)\end{array}$ & $\mathrm{I}(0)$ \\
\hline
\end{tabular}

(Note) $p$-value in parenthesis. SIC was used for lag length selection for ADF. In the case of PP, spectral estimation method using Bartlett kernel and Newey-West for bandwidth. Estimated without exogenous variables (in specifications including constant and/or trend, those variables were not statistically significant as expected). 


\section{Determinants of the Structural Component of the Eurozone External Imbalances}

In this section, we analyse the determinants of the SCEB. To extract the structural component, we use the methodology described in the previous section (SCBp). In addition, we contrast our proposal against three other methods for identifying the structural component (or medium-term trends) widely used in the economic literature: non-overlapping 5-year averages, as in Chinn and Prasad (2003) and two statistical techniques for the decomposition of the series - namely, the Hodrick and Prescott filter as in Hodrick and Prescott (1997; hereafter HP) and univariate Structural Time Series models as developed by Koopman et al. (2006), Harvey (2006), and Harvey and Shephard (1993); hereafter STS.

Figure 4 shows the SCEB for each EA-12 country using the four methodologies described above. As shown, the trends are very similar using all four methods. However, our SCBp proposal is more stable, and transitory shocks do not skew significantly skew the results.

To analyze the determinants of the SCEB, we return to Equation 2. In this case, the SCEB would depend on a set of variables related to the economic structure, demographic factors, institutional framework, financial development, and the role of the public sector. Variables are available to all examined countries for the period 1996 2014. The detailed description of the variables (abbreviation, source, and date of consultation) are given in the Appendix.

Regarding the economic structure, GDP per capita (GDPpc) is used as an approximation of the level of development; high-tech exports (High_tech) and R\&D expenditure (RandD_exp) represent economic specialization. We also include trade openness (Trade). We expect that all these variables will have a positive relationship with the external balance. 


\section{Figure 4. Structural component of EA-12 external balance}

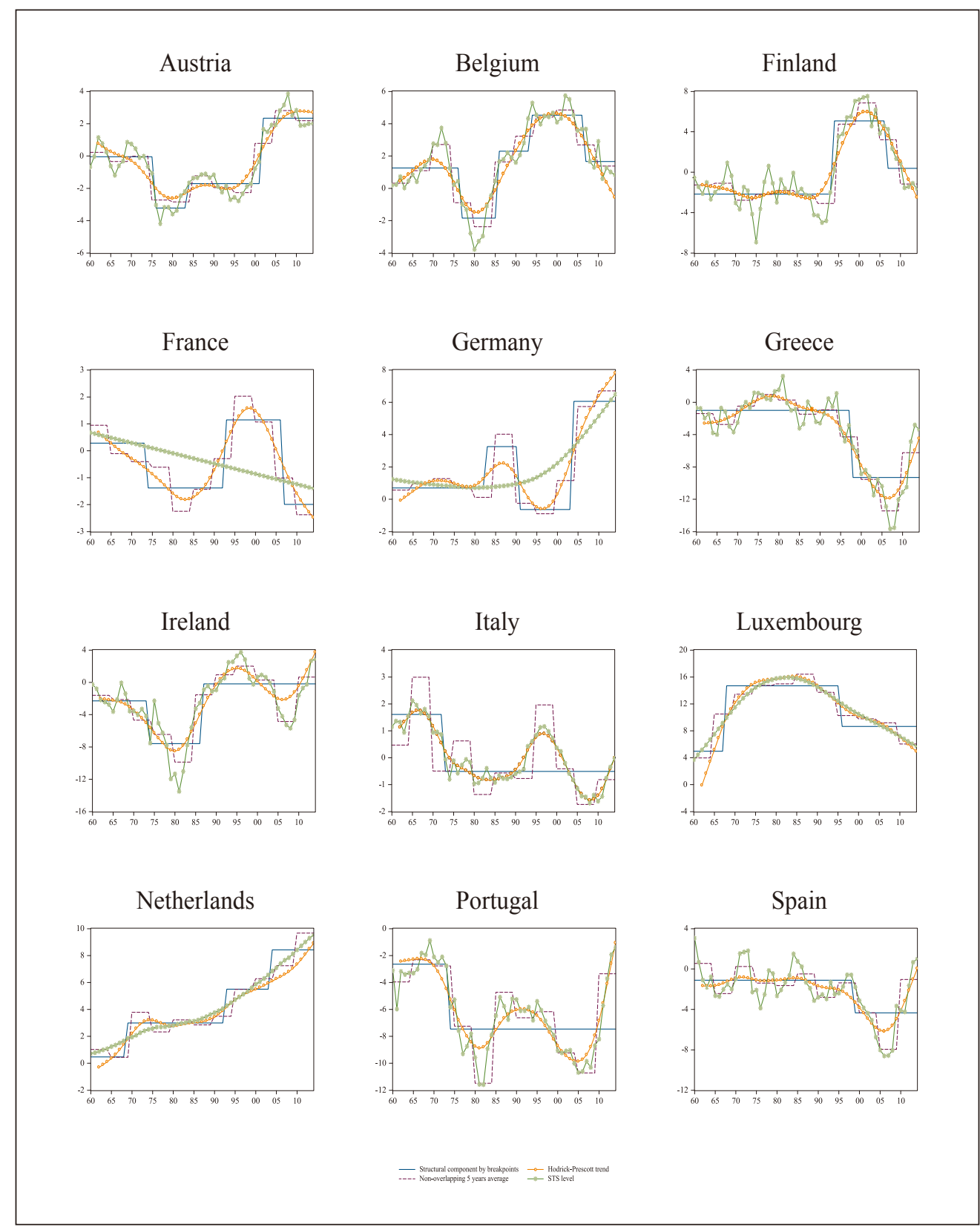

(Note) Structural component by breakpoints refers to our proposal. HP filter estimated with $\lambda=100$. STS estimation included level (stochastic), slope (stochastic); irregular and cycle (5 years). STM was estimated by Maximum Likelihood (exact score). For Belgium, no cycle was appropriate. 
Regarding demographic factors, we use the young-age dependency ratio (Young_dep) and old-age dependency ratio (Old_dep). In this case, we expect that countries with younger populations will exhibit a negative relationship with the external balance whereas in the case of the old-age dependency ratio, the relationship is more complex. An aging society will present a high rate of savings to address future expenditure associated with such societies. However, once the society reaches the old-age stage, a deficit will be observed (dissaving process).

In the case of the financial system's structure, the domestic credit provided by the financial sector (Credit_by_fin) is used as a proxy for the depth of the financial system, and net foreign assets (NFA_merge) is used as a measure of financial openness. In both cases, a positive relationship with the external balance is expected. In relation to the institutional framework, political stability (Pol_stability) and regulatory quality (Reg_quality) are used, and a positive sign is expected for both variables. Finally, with regard to government involvement in the economy, we use government deficit/ surplus (Gov_position), with a positive sign expected due to the twin deficits hypothesis.

As stated above, one aim in this article -in addition to identifying the structural component of Eurozone external imbalances and analyzing its determinants- is to contrast the proposed SCBp with other widely used approaches in the economic literature. Therefore, we estimate seven models. Firstly, we estimate the determinants of the SCEB using the SCBp methodology. In this case, we obtain the averages of the variables for each sub-period in accordance with Table 1. Due to data unavailability, in cases in which data do not cover the entire sub-period, we use an average for the available years, starting in 1996. Secondly, we follow the methodology of Chinn and Prasad (2003) by using non-overlapping 5-year periods in a panel data framework with time effects. Later, in the third and fourth estimates, the trend and level obtained with the HP filter and STS modeling, respectively, are used as dependent variables. In this case, panel data with time effects are also used. Finally, the fifth estimate is made within a panel data framework with time effects using the original variable BRM.

Table 3 shows the estimation results for the baseline model following the aforementioned strategy. Results in Table 3 were derived using $B R M_{-}$ $H P, B R M \_S T S$, and the original BRM series as dependent variables (models 
3,4 , and 5 , respectively). In this case, the results are essentially the same when using the three different dependent variables, with the only exception of the significance of the GDPpc variable when the structural component is approximated by the HP trend. In this case, the external balance is explained by a country's economic structure as reflected in economic specialization (High_tech and RandD_exp) and trade openness (Trade), the aging process (Old_dep), and institutional factors such as the political stability ( $\mathrm{Pol}_{-}$ stability) and the regulatory quality (Reg_quality). 


\begin{tabular}{|c|c|c|c|c|c|c|c|c|c|c|c|}
\hline$\frac{n}{\frac{0}{0}}$ & 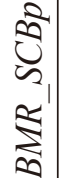 & 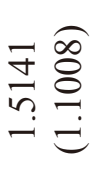 & & 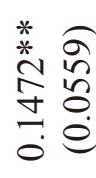 & & & & & & 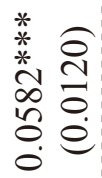 & \\
\hline $\begin{array}{l}0 \\
\frac{0}{0} \\
\frac{0}{2}\end{array}$ & 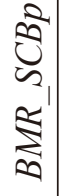 & 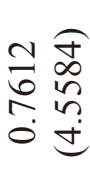 & & 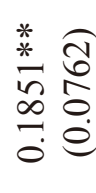 & 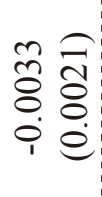 & & & $\begin{array}{l}\text { I } \\
=1 \\
= \\
0\end{array}$ & & 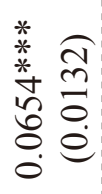 & \\
\hline $\begin{array}{l}n \\
\frac{0}{0} \\
\frac{0}{2} \\
\sum\end{array}$ & 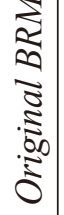 & 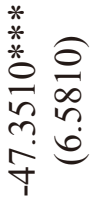 & $\begin{array}{l}\overline{8} \\
\overline{8} \\
8 \\
0 \\
0\end{array}$ & 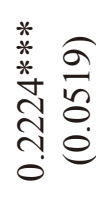 & 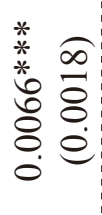 & \begin{tabular}{lc}
$*$ & 0 \\
$*$ & 0 \\
\multirow{*}{*}{} & 0 \\
0 & 0 \\
0 & 0 \\
0 & 0
\end{tabular} & $\begin{array}{l}n \\
\frac{n}{0} \\
\stackrel{0}{\Xi} \\
0 \\
0\end{array}$ & 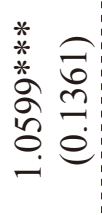 & 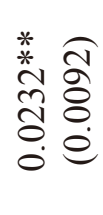 & 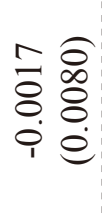 & 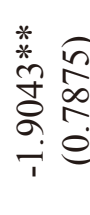 \\
\hline$\frac{ \pm}{\frac{\pi}{\sigma}}$ & $\begin{array}{l}\sum_{1} \\
\sum_{1} \\
\sum_{\infty}^{\prime}\end{array}$ & 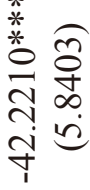 & $\begin{array}{l}\overline{8} \\
\overline{8} \\
8 \\
0 \\
0\end{array}$ & 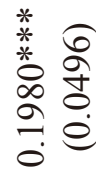 & 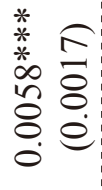 & 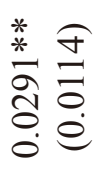 & 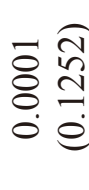 & 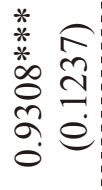 & 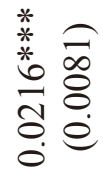 & $\begin{array}{l}\sqrt{8} \\
8 \\
8 \\
0 \\
0 \\
\dot{1}\end{array}$ & 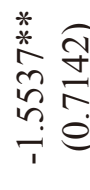 \\
\hline$\frac{m}{\frac{m}{0}}$ & 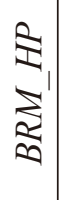 & 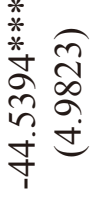 & $\begin{array}{ll}* & \\
* & 8 \\
* & 8 \\
\circ & 8 \\
8 & 0 \\
0 & 0 \\
0 & 0\end{array}$ & 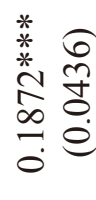 & 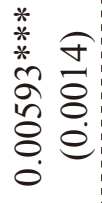 & \begin{tabular}{l}
$*$ \\
\multirow{*}{*}{} \\
$\stackrel{8}{0}$ \\
$\stackrel{0}{0}$ \\
0 \\
0 \\
0
\end{tabular} & $\begin{array}{l}\circ \sqrt{n} \\
2 \\
\stackrel{2}{\equiv} \\
0 \\
0\end{array}$ & 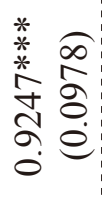 & 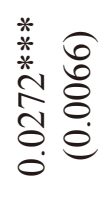 & 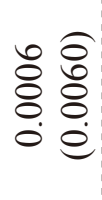 & 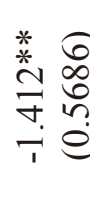 \\
\hline$\frac{N}{\frac{N}{0}}$ & 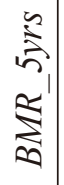 & 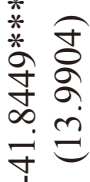 & 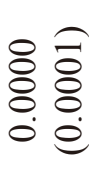 & 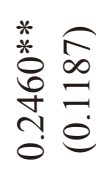 & 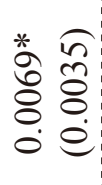 & 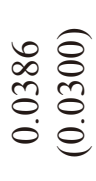 & 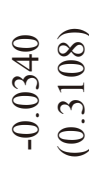 & 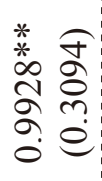 & 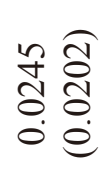 & 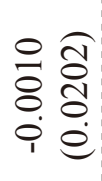 & $\begin{array}{l}\overrightarrow{0} \\
0 \\
0 \\
0 \\
i \\
i\end{array}$ \\
\hline$\frac{-}{\bar{\theta}}$ & 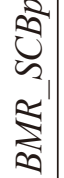 & 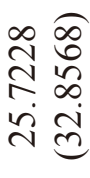 & 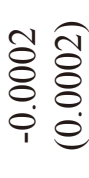 & 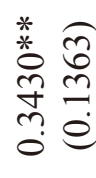 & $\begin{array}{l}n \\
0 \\
8 \\
0 \\
0 \\
0\end{array}$ & 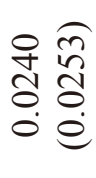 & $\begin{array}{l}\infty \\
\stackrel{2}{2} \\
\hat{n} \\
i \\
i\end{array}$ & 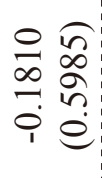 & $\begin{array}{l}\circ \\
\stackrel{0}{0} \\
\stackrel{0}{0} \\
0 \\
0\end{array}$ & 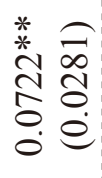 & $\begin{array}{l}0 \\
\stackrel{0}{0} \\
\stackrel{5}{a} \\
\dot{1}\end{array}$ \\
\hline \multicolumn{2}{|c|}{ 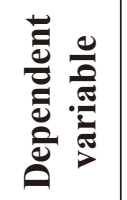 } & ర్ & 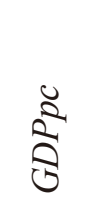 & 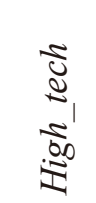 & 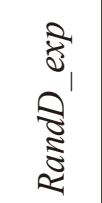 & సี & $\begin{array}{c}0 \\
\stackrel{0}{\Xi} \\
\vdots\end{array}$ & $\begin{array}{l}\frac{8}{0} \\
\frac{\pi}{0}\end{array}$ & $\begin{array}{l}\sqrt[2]{0} \\
3 \\
0 \\
0 \\
0 \\
0\end{array}$ & $\begin{array}{l}\infty \\
\infty \\
\vdots \\
\vdots \\
\vdots \\
z \\
z\end{array}$ & 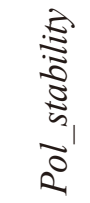 \\
\hline
\end{tabular}




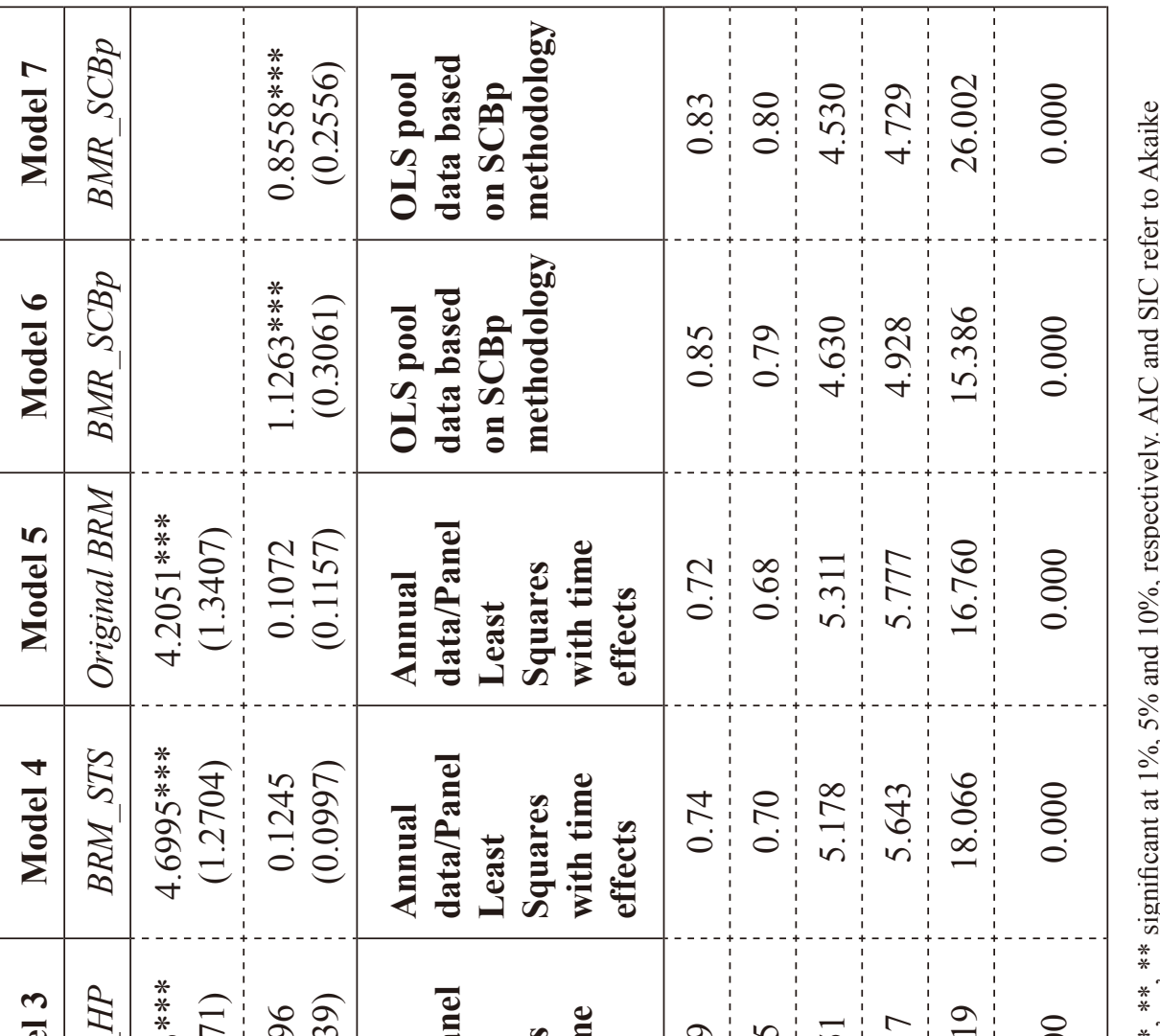

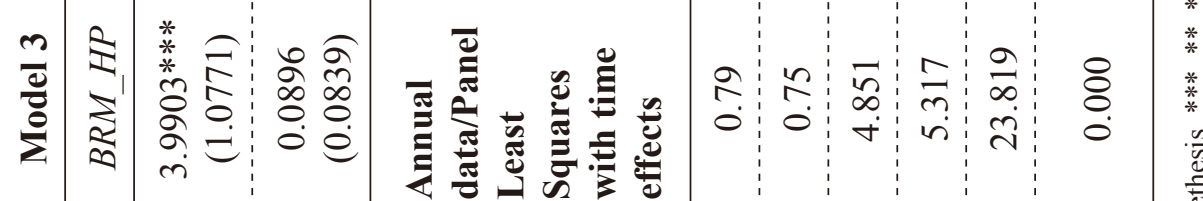

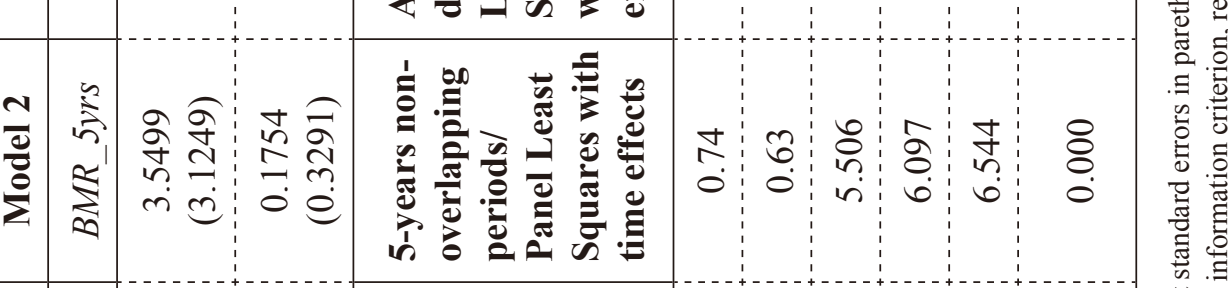

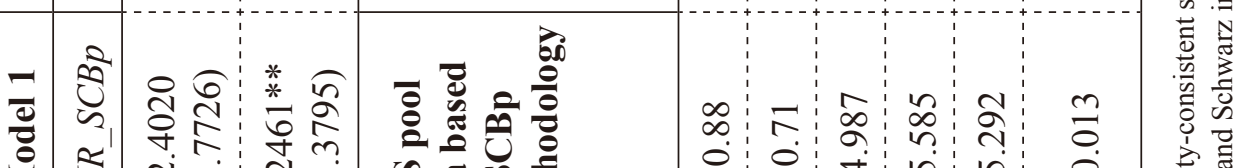

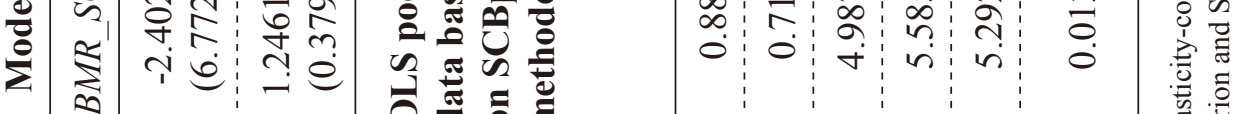

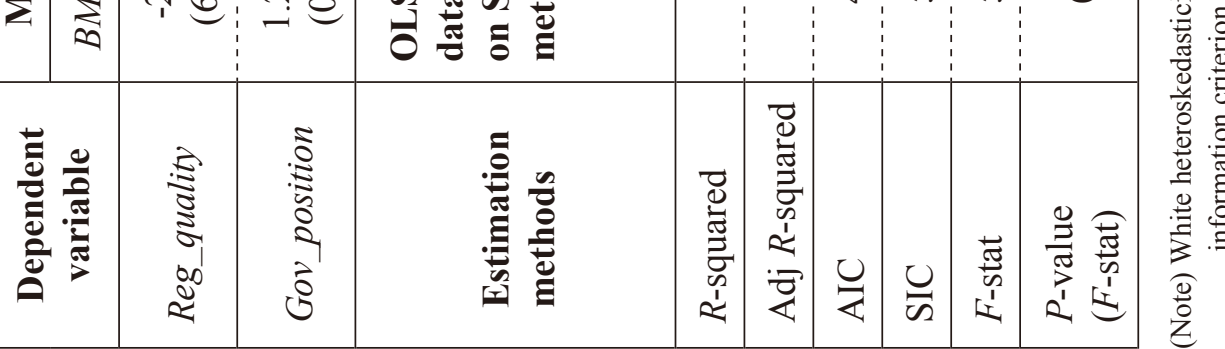


However, given the similarities in the estimates from models 3, 4, and 5, if the objective is to analyze the determinants of the SCEB, the use of $B R M_{-} H P$ and BRM_STS variables is not suitable because-similar to using the original BRM variable -it would not be possible to isolate the factors explaining the purely structural component. The similarity in the results when SCEB is extracted by filtering techniques and when using the original variable $B R M$ reflects the fact that in the filtering techniques, the trend is highly correlated with the cycle component such that the trend component is skewed even when a strong temporal deviation is present.

Besides, as shown in model 2 of Table 3 -which uses non-overlapping 5-year averages- the economic structure (High_tech and RandD_exp) and the aging process (Old_dep) are both key factors explaining medium-term trends of the external balance. Meanwhile, when using as the dependent variable -our proposal in model 1- the key factors explaining the SCEB are the exports structure (reflecting economic specialization), net foreign assets (financial openness), and government deficit/surplus. In this case, the point to note is that in the five different estimates (models 1 to 5), the economic structure reflected in high-tech exports appears to be key in explaining the SCEB.

As robustness checks, the last two columns of Table 3 present the results of estimations using only BRM_SCBP as the dependent variable. In addition, the number of explanatory variables is restricted to those having significance in the estimates of model 1 and/or model 2, which would reflect the structural component (model 1) or medium-term trends (model 2). In this case, the significance of High_tech (export specialization), NFA_merge (financial openness) and Gov_position (twin deficits) is reaffirmed. Finally, we restrict the explanatory variables to those that had statistical significance in models 1 and 6, that is, using BRM_SCBP as a dependent variable. In this case, results indicate a high similarity in parameter magnitudes when High_tech, NFA_ merge, and Gov position are statistically significant. Finally, when comparing models 1,6 , and 7 , the adjusted $R$-squared and information criteria indicate a better fit for model 7 .

In summary, the factors that explain the SCEB are the export specialization, openness of the financial system, and the government deficit/surplus. In this regard, our main contribution focuses on identifying the presence of the SCEB and its determinants to implement economic policy action to address these permanent disparities. 
However, the results could be clarified by determining which factors explain the differences in the structural components of the external imbalances among Eurozone members, along with delineating how changes in those variables were transmitted to the external balance. In the first case, export specialization in high-added-value industries in surplus countries indicates disparities in non-price competitiveness -e.g., quality, variety, and exclusiveness of export goods and services- among European economies. Export specialization in high-added-value industries reflects an economic structure that enables those countries to enter and adapt to an integrated world economy without directly competing with price-competitive developing economies. This is, the entrance of global competitors -such as China into the world economy- does not jeopardize the evolution of trade performance in those surplus countries in the short term because their trade advantages exist not in price-competitive industries but in non-price-competitive ones.

In the second case, economic and financial integration in the Eurozone helped generate positive expectations of future economic growth in peripheral countries. In this regard, given the expected catching-up and higher marginal returns in those relatively less developed countries, capital flowed from core to periphery countries, with core Eurozone countries functioning as financial intermediaries vis a vis the rest of the world in a global context of high liquidity. These capital flows were reflected in increased investment relative to savings and, therefore, in deterioration of the external balance.

In the third case, the relationship between the public sector balance and SCEB has at least three possible explanations. First, this relationship could reflect social preferences regarding public sector intervention in the economy. Another explanation is that economic policy in some core countries could be designed to maintain relatively depressed domestic demand to keep a competitive external sector. Finally, peripheral countries governments could have incentive to borrow because of the relatively low interest rates resulting from financial integration in a context of global high liquidity.

\section{Final Remarks}

This article examined the existence of SCEB in EA-12 countries. The SCEB is defined as the unobservable part of the external balance that is stable 
or evolves slowly and around which fluctuations exist with a potentially cyclical origin that are corrected in the short term.

We proposed a methodology to identify the SCEB for EA-12 countries, called Structural Component by Breakpoints (SCBp). The proposed SCBp approach made it possible to indicate the presence and persistence of a structural surplus in Belgium (moderate surplus), Germany, Luxembourg, and the Netherlands, whereas Greece (mainly since the adoption of the euro), Portugal, and Spain have observed structural deficits.

Some advantages of the proposed method were highlighted in comparison with other widely used techniques. First, the selection of the starting year for each period is not made in a discretionary manner. Second, use of unit root tests allows us to identify whether variations around the structural component are temporary and whether use of our proposed method is suitable. Third, in the proposed SCBp approach, the presence of a strong temporal deviation does not significantly skew the SCEB results, unlike the case when filtering techniques are implemented. Finally, our proposed SCBp approach does not require strong assumptions regarding the functional form of the variables.

However, the proposed approach does have some limitations. For example, this technique can lead to having too few observations if the goal is to analyze the determinants of the structural component. However, this can be remedied by increasing the number of studied countries, albeit with the condition that the included countries are relatively homogeneous. Another disadvantage is that the structural component cannot be identified in real time.

Finally, this study investigated the determinants of the SCEB. Our results indicated that the export structure, as a reflection of economic specialization, financial openness, and the government deficit/surplus are key variables explaining the SCEB.

Some implications may be drawn from the analyses in this study. On the one hand, given the structural origin of surpluses (in the case of Belgium, Germany, Luxembourg, and the Netherlands) and deficits (in the case of Greece, Portugal, and Spain), cyclical economic policies will only have temporary effects on external imbalances. That is, the structural origin of imbalances will remain intact; thus, such imbalances should be expected to reappear.

Therefore, if the goal is to address permanent disparities in the structural component of external imbalances among Eurozone member countries, 
economic policy should focus on the determinants of those imbalances. In this regard, two relevant points can be made. First, a European industrial policy allowing for development of an export structure with higher added value in countries with a structural deficit would have potentially positive effects on their external balance. This highlights the need to deepen the current debate on the potential benefits of an active industrial policy in Europe, as pointed out by Botta (2014), Mazzucato et al. (2015), Andreoni and Chang (2016), Ambroziak (2017), and Peneder (2017).

Second, permanent moderation in the fiscal balance would help to correct the structural part of the external balance related to the twin deficits hypothesis. However, a fiscal consolidation plan could cause several problems, such as (1) output losses, as pointed out by Yang, Fidrmuc, and Ghosh (2015) and Heimberger (2017); (2) an increase in income inequality, as found by Agnello and Sousa (2014); and (3) a reduction of human development standards, as highlighted by Agnello, Castro, Jalles, and Sousa (2017). These effects on output and income inequality depend on the structure of the fiscal consolidation plan, i.e., expenditure-cuts-based or tax-based fiscal adjustment, as affirmed by Alesina, Favero, and Giavazzi (2015), Yang, Fidrmuc, and Ghosh (2015), and Agnello and Sousa (2014). In addition, any fiscal adjustment should reallocate fiscal expenditure to areas able to increase the economy's productive capacity.

However, these two steps (an active European industrial policy and a fiscal adjustment) seem to be contradictory. Is an active industrial policy consistent with a moderation in the fiscal balance? The answer depends on how this European industrial policy would be financed. One option that should be analyzed in depth is the possible involvement by the European Investment Bank in this new re-industrialization. Another option is the implementation of a golden rule of public investment, as proposed by Truger (2016). 


\section{References}

Agnello, L. and Sousa, R.M., "How Does Fiscal Consolidation Impact on Income Inequality?" Review of Income and Wealth 60(4) (2014): 702-726.

Agnello, L., Castro V., Jalles, J.T. and Sousa, R.M., "The Impact of Fiscal Consolidation on Human Development". Journal of International Development 30(3) (2018): 399-429.

Aizenman, J. and Sengupta, R., "Global Imbalances: Is Germany the New China? A Skeptical View." Open Economies Review 22 (2011): 387-400.

Alesina, A., Favero, C. and Giavazzi, F., "The output effect of fiscal consolidation plans." Journal of International Economics 96 (2015): S19-S42.

Alessandrini, P., Fratianni, M., Hallett, A.H. and Presbitero, A.F. "External Imbalances and Fiscal Fragility in the Euro Area." Open Economies Review 25 (2014): 3-34.

Algieri, B., "An empirical analysis of the nexus between external balance and government budget balance: The case of the GIIPS countries." Economic Systems 37 (2013): 233-253 .

Ambroziak, A.A., "A Theoretical Concept of a Modern Industrial Policy," in The New Industrial Policy of the European Union, ed. Ambroziak A. (Contributions to Economics. Springer, 2017) 173-186.

Andreoni,A. and Chang, H-J., "Industrial policy and the future of manufacturing." Economia e Politica Industriale 43(4) (2016): 491-502.

Arghyrou, M.G. and Chortareas, G., "Current Account Imbalances and Real Exchange Rates in the Euro Area." Review of International Economics 16 (2008): 747-764. 
Bai, J., "Estimating Multiple Breaks One at a Time." Econometric Theory 13 (1997): 315.

Bai, J. and Perron, P., "Estimating and Testing Linear Models with Multiple Structural Changes." Econometrica 66 (1998): 47-78.

Bai, J. and Perron, P., "Critical values for multiple structural change tests." Econometric Journal 6 (2003): 72-78.

Barnes, S., Lawson, J. and Radziwill, A., "Current Account Imbalances in the Euro Area. A Comparative Perspective," OECD Economics Department Working Papers 826 (2010), http://www.oecd-ilibrary.org/economics/currentaccount-imbalances-in-the-euro-area_5km33svj7pxs-en, accessed 21 March 2013.

Belke, A. and Dreger, C., "Current Account Imbalances in the Euro Area: Does Catching up Explain the Development?" Review of International Economics 21 (2013): 6-17.

Blanchard, O.J. "Current Account Deficits in Rich Countries." IMF Staff Papers 54(2) (2007): 191-219.

Blanchard, O.J. and Giavazzi, F., "Current Account Deficits in the Euro Area: The End of the Feldstein-Horioka Puzzle?" Brookings Papers on Economic Activity 33(2) (2002): 147-210.

Botta, A., "Structural asymmetries at the roots of the eurozone crisis: what's new for industrial policy in the EU?" PSL Quarterly Review 67 (2014): 169216.

Brissimis, S.N., Hondroyiannis, G., Papazoglou, C., et al "The determinants of current account imbalances in the euro area: A panel estimation approach." Economic Change and Restructuring 46 (2013): 299-319. 
Campa, J.M. and Gavilan, A., "Current accounts in the euro area: An intertemporal approach." Journal of International Money and Finance 30 (2011): 205-228.

Chen, R., Milesi-Ferretti, G.M. and Tressel, T. "External imbalances in the eurozone.” Economic Policy 28 (2013): 101-142.

Cheung, C., Furceri, D. and Rusticelli, E., "Structural and Cyclical Factors behind Current Account Balances." Review of International Economics 21 (2013): 923-944.

Chinn, M.D. and Prasad, E.S., "Medium-term determinants of current accounts in industrial and developing countries: an empirical exploration." Journal of International Economics 59 (2003): 47-76.

D'Auria, F., Denis, C., Havik, K., McMorrow, K., Planas, C., Raciborski, R., Röger, W. and Rossi, A., "The Production Function Methodology for Calculating Potential Growth Rates \& Output Gaps." European EconomyEconomic Papers 420 (2010). http://ec.europa.eu/economy_finance/publications/ economic_paper/2010/pdf/ecp420_en.pdf., accessed 22 September 2015.

Deutsche Bundesbank (2001) "Structural current account balances: longer-term trends and determinants." Deutsche Bundesbank Monthly Report January 2001, http:/www.bundesbank.de/Redaktion/EN/Downloads/Publications/Monthly Report_Articles/2001/2001_01_current_account.pdf?_blob=publicationFile, accessed 9 December 2015.

Dickey, D.A. and Fuller, W.A. "Distribution of the Estimators for Autoregressive Time Series with a Unit Root." Journal of the American Statistical Association 74 (1979): 427-431.

Dickey, D.A. and Fuller, W.A., "Likelihood Ratio Statistics for Autoregressive Time Series with a Unit Root." Econometrica 49 (1981): 1057-1072. 
Gehringer, A., "New evidence on the determinants of current accounts in the EU.” Empirica 42 (2015): 769-793.

Harvey, A., "Chapter 7 Forecasting with Unobserved Components Time Series Models," in Handbook of Economic Forecasting, Ed. Elliott, G., Granger, C.W.J. and Timmermann, A. (North Holland, 2006) 327-412.

Harvey, A.C. and Shephard, N., "10 Structural time series models," in Handbook of Statistics (Elsevier Science, 1993), 261-302.

Hassan, A., Salim, R. and Bloch, H. "Population age structure, saving, capital flows and the real exchange rate: A survey of the literature." Journal of Economic Survev 25 (2011): 708-736.

Heimberger, P. "Did fiscal consolidation cause the double-dip recession in the euro area?" Review of Keynesian Economics 5 (2017): 439-458.

Hodrick, R.J. and Prescott, E.C. "Postwar U.S. Business Cycles: An Empirical Investigation.” Journal of Money, Credit and Banking 29 (1997): 1-16.

Koopman, S.J., Harvey, A.C., Doornik, J.A. and Shephard, N., STAMP 8.0: Structural Time Series Analyser, Modeller and Predictor. London: Timberlake Consultants, 2006.

Lane, P.R. and Milesi-Ferretti, G.M. "The external wealth of nations mark II: Revised and extended estimates of foreign assets and liabilities, 1970-2004." Journal of International Economics 73 (2007): 223-250.

Lane, P.R. "International Financial Integration and the External Positions of Euro Area Countries." OECD Economics Department Working Papers 830 (2010), http://www.oecd-ilibrary.org/economics/international-financial-integrationand-the-external-positions-of-euro-area-countries_5km33sqg0m9s-en. accessed 15 January 2014. 
Matsubayashi, Y., "Structural and cyclical movements of the current account in Japan: An alternative measure." Japan and the World Economy 18 (2006): $545-567$.

Mazzucato, M., Cimoli, M., Dosi, G., et al "Which Industrial Policy Does Europe Need?" Intereconomics 50 (2015): 120-155.

Orlandi, F. (2012) Structural unemployment and its determinants in the EU countries. European Economy-Economic Papers 455 (2012), http://ec.europa. eu/economy_finance/publications/economic_paper/2012/pdf/ecp_455_en.pdf. accessed 22 September 2015.

Peneder, M. "Competitiveness and industrial policy: from rationalities of failure towards the ability to evolve." Cambridge Journal of Economics 41(3) (2017): 829-858, https://doi.org/10.1093/cje/bew025.

Phillips, P.C.B. and Perron, P., "Testing for a Unit Root in Time Series Regression.” Biometrika 75 (1988): 335.

Schmitz, B. and von Hagen, J. "Current account imbalances and financial integration in the euro area." Journal of International Money and Finance 30 (2011): 1676-1695.

Truger, A. "Reviving fiscal policy in Europe: towards an implementation of the golden rule of public investment." European Journal of Economics and Economic Policies: Intervention 13 (2016): 57-71.

Yang, W., Fidrmuc, J., and Ghosh, S., "Macroeconomic effects of fiscal adjustment: A tale of two approaches." Journal of International Money and Finance 57 (2015): 31-60. 


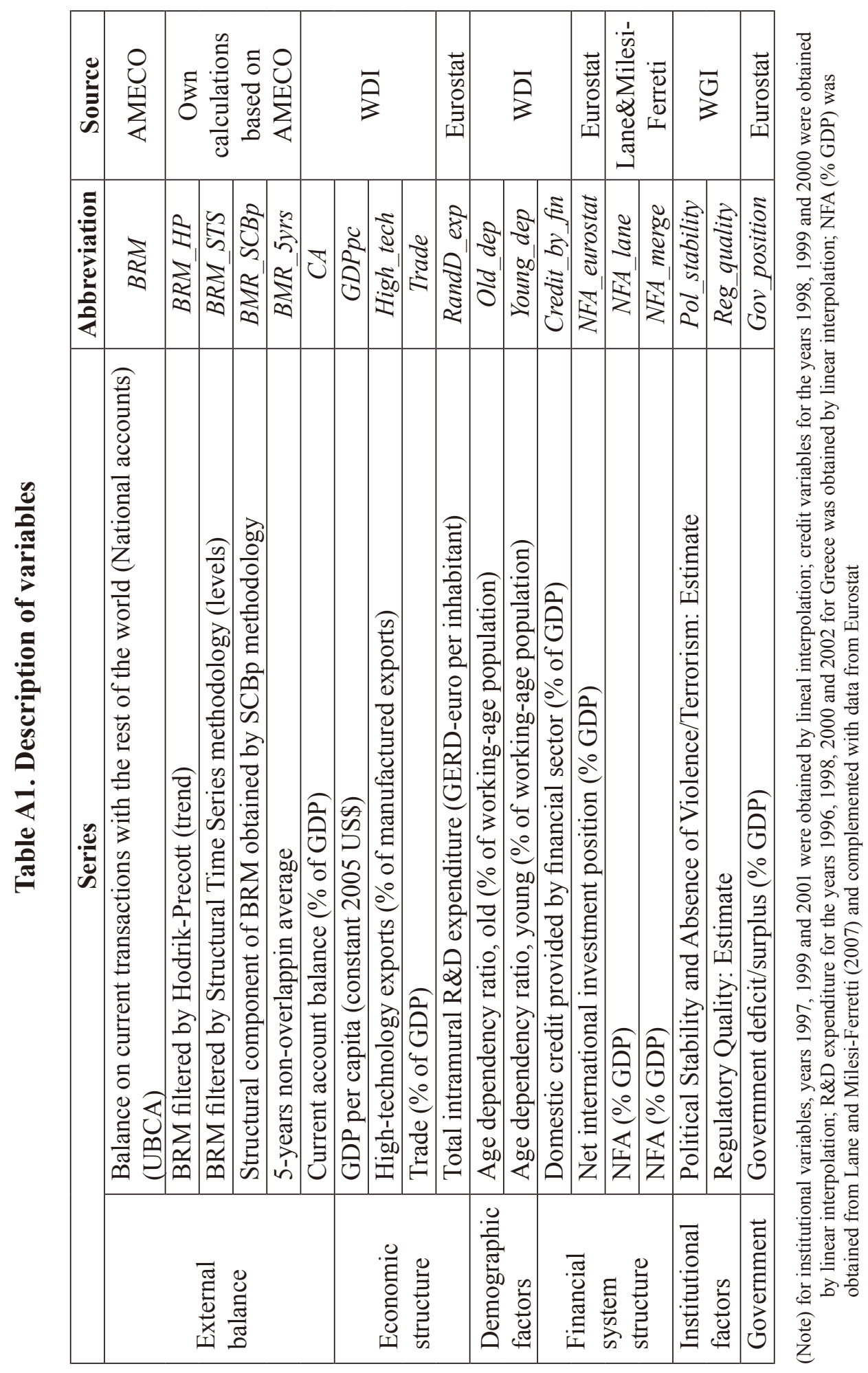

